\title{
THE ABILITY OF ISLAMIC BOARDING SCHOOL STUDENTS IN FACING THE DIGITAL LITERACY ERA WITH CRITICAL READING
}

\author{
Anwar Hafidzi \\ Faculty of Shariah \\ Islamic State University Antasari, Banjarmasin. Kalimantan Selatan \\ e-mail: anwar.hafidzi@uin-antasari.ac.id
}

\begin{abstract}
In order to develop information technology, the national education system must be improved, and Pondok Pesantren is no exception. Since the ratification of Islamic Boarding School Law there have been at least four key fields, including the eight aspects of digital-age literacy, core literacy, science, information, visuals, technology, multicultural awareness and global knowledge. The tool used in the present study was to develop the teaching abilities of Islamic boarding school students and to write them through a bibliography approach and approach to education through Kelvin Seifert's digital literacy techniques, opportunities and challenges. These findings show the students' ability to learn and comprehend it again with good analytics can be enhanced with the approach to classical book studies with critical thinking skills.
\end{abstract}

Keywords: Ability; Digital-Age Literacy; Islamic education; boarding school; 


\section{A. Introduction}

One of the skills of the 21st century, which is important for the Indonesian government to focus on literacy. Although different studies have shown that in Indonesia, the level of education in comparison to other countries is still relatively small.(Ratri, 2015) A study by the PIRLS found that Indonesians hold the lower position with a score of 51.7. In addition, Indonesian students have a score of 41.5. In between, Thailand received a score of 52.6, Singapore 74.0 and Hong Kong 75.5. (Setiawan, 2019; Suwono, 2017; Suwono dkk., 2017; Teo, 2019)

Indonesia ranked 39th out of a total of 40 countries in other research conducted by PISA on Indonesia's literacy skills in 2003.(Nugrahanto \& Zuchdi, 2019) Indonesia ranked 48 out of 56 countries surveyed in 2006, while Indonesia ranked 57 out of 65 countries in 2009, while Indonesia ranked 64 out of 65 countries in 2012.(Ratri, 2015) The results of this study are also supported by research conducted by PIRLS on 4th grade students from 45 developed and developing countries, with Indonesia ranked 41st.(Abdulkarim dkk., 2018)

Today's advances in Information Technology (IT) and the internet have resulted in an abundance of digital information resources. Everyone is free to enter data without constraints in cyberspace. In digital native terms it is mentioned that the young generation is now living in the digital age, where the internet is part of everyday life. In finding information, the current condition of students, especially high school students, is highly dependent on search engines like Google.(Graham \& Dutton, 2019; Van Knippenberg dkk., 2015) It results in a decreased use of the available performance tools in school libraries as well as improvements in student behavior in knowledge use and management.

The different studies above provide a summary of Indonesia's literacy conditions that are still listed in the low group. The fact that literacy skills are still weak is reflective of the government's need for education. To tackle this problem of literacy requires cooperation and coordination from different parties, including state, universities, student parents, community, educators, and students, of course. 
Table 1. Aspects of 21st century skills in the domain Digital age literacy (Germaine dkk., 2016)

\begin{tabular}{|c|c|}
\hline Skills & Aspects \\
\hline Basic & $\begin{array}{l}\text { 1. Speak (read, write, listen, speak) } \\
\text { 2. Numerical (arithmetic computing, mathematical } \\
\text { reasoning) }\end{array}$ \\
\hline Scientific & $\begin{array}{l}\text { 1. Having knowledge and understanding of scientific } \\
\text { concepts and processes } \\
\text { 2. Analyzing answers from curiosity is based on } \\
\text { experience } \\
\text { 3. The ability to describe, explain, and predict natural } \\
\text { phenomena } \\
\text { 4. Read and understand scientific articles } \\
\text { 5. Identify scientific issues } \\
\text { 6. Evaluate the quality of scientific information }\end{array}$ \\
\hline Economic & $\begin{array}{l}\text { 1. Identifies economic problems at the local level } \\
\text { 2. Identifying economic problems at the global level }\end{array}$ \\
\hline Information & $\begin{array}{l}\text { 1. Before accessing information (differentiate what you } \\
\text { want to know and need from different sources based } \\
\text { on source credibility) } \\
\text { 2. When accessing information (identifying relevant } \\
\text { information) } \\
\text { 3. After the information is obtained (using for specific } \\
\text { purposes using a number of tools and media) }\end{array}$ \\
\hline Technological & $\begin{array}{l}\text { 1. Use of various technologies to increase productivity } \\
\text { 2. Use various communication tools to communicate } \\
\text { ideas to others. } \\
\text { 3. Using technology to solve problems }\end{array}$ \\
\hline
\end{tabular}




\begin{tabular}{|l|l|}
\hline Visual & $\begin{array}{l}\text { 1. Understand the basic elements of visual design } \\
\text { 2. Applying the knowledge acquired in electronic } \\
\text { media visually }\end{array}$ \\
\hline Multicultural & $\begin{array}{l}\text { 1. Understanding and appreciating the similarities and } \\
\text { differences in values, beliefs, and culture } \\
\text { 2. Sensitivity to information that contains ethnicity, } \\
\text { race, religion etc. } \\
\text { 3. Studying other cultures }\end{array}$ \\
\hline Global & $\begin{array}{l}\text { 1. Having awareness about global issues } \\
\text { 2. Having knowledge about global problems } \\
\text { 3. Analyzing ways of solving global problems }\end{array}$ \\
\hline
\end{tabular}

The diversity of information forms and types should encourage students to be more selective and to maximize the utilization of advances on information technology with table 1 . Development in the world of the 21st century is characterized by the use of information and communication technology (ICT) in all walks of life. Technology connects the world beyond geographical barriers, making the world unlimited. The advancement of ICT through the Internet makes it easier to learn, to enterprise and even to send money. Technological developments are bringing about improvements to workplace training and skills. This is of course required today and how Pesantren (Islamic boarding school) can keep up with global technology development today.

Changes to expectations in the 21st century include changes of the academic system in the area of training of pupils, high school or high school and the equivalent of boarding schools. IT promotes contact between members of the public and the workforce which is not constrained by time and space. This is how the digital world can become a significant part of Islamic boarding schools' education. Addressing the changing trends of needs and change in the workplace, Islamic boarding schools need to be ready and prepared to face 21st century challenges. Learning the skills of the 21st century is necessary for students to learn. Compliance with the apps, achievement methods and training approaches practiced can contribute to 21st century skills. The focus of this study is on 
how well-known scholars in religious studies can be prepared and strategized to write classical books?

\section{B. Method}

This work uses literature analysis to examine the results and use the approach to phenomenology(Eddles-Hirsch, 2015) to see the growth of students in several internships in South Kalimantan. This methodology is used to see the growth of student learning programs with face-to-face classical and secular studies in several Islamic boarding schools and to see the potential they need to be ready in the future.

\section{Finding and Discussion}

\section{Finding: Ability to read and write Classical Arabic}

Among the various components of basic literacy, the researchers concentrate on basic literacy, which is the ability to listen, speak, read, compose, and measure the analytical ability to take into account, plan data, communicate, and explain information based on personal understanding and deduction. Students ' ability to read Arabic books is a significant starting point in student life in a number of Islamic boarding schools in southern Kalimantan.

Here are a number of pesantren such as al-falah Islamic boarding school, darul ilmi, darul hijrah, darussalam, pamangkih or others whose basic training is to use classical Arabic books (kitab kuning) directly with the teacher. These abilities will be able to increase and be effective in the 21 st century if, through two phases of literacy:

a. Thinking Critical Skills, The critical way of thinking is one of the strongest thinking skills or HOTS apart from creative thought, creative thinking and problem-solving.(Howard dkk., 2015) The capacity of someone to evaluate a concept using logical reasoning can be said to be critical thinking skills. Critical thinking abilities may also mean the ability to think in decisionmaking. Based on the analysis of the expert, it can be inferred that the ability to think critically, reflectively, systematically, 
and productively is critical thinking capacity that is applied in making good judgment and making decisions. (Ulger, 2016)

b. One of the life skills that need to be built through the educational process is the Importance of Critical Thinking Skills Thinking skills. The ability of a person to think will affect one's life's success because of the ability to think about what is going to be done. That education in school-based thought not only stresses the acquisition of subject-matter knowledge, but the students ' ability to obtain their own (self-regulated) knowledge is a priority. (Deng $\&$ Gopinathan, 2016; Scott, 2018)

Somebody with critical thinking skills tends to identify relevant information more quickly, disclose irrelevant information and use it to find solutions or decide, and find, if necessary, relevant supporting information. Someone needs and needs to learn critical thinking skills, because these skills are useful and a preparation for life today and in the future. A person can rationally and logically reflect on the reception of information and on the systemic resolution of problems by critical thoughts. This means that critical thinking can improve analytical skills.

\section{Discussion: Learning Process: The learning Skill of the Student}

This is a transition process that takes place in students as a result of a number of interactions, both in the form of awareness, attitudes and skills. Since education in a student is a process of change, learning will only take place when students have an internal urge to change according to their abilities and potential. The essence of the learning process, namely: aspects of how knowledge is learned and how new knowledge is linked to existing structures. In the first level, distinct learning styles that are searching for the second are differentiated from learning that is being pursued (Discovery Learning) that is being received (Reception Learning).(Ramdhani \& Muhammadiyah, 2015) There is a meaningful second dimension (meaningful learning). In the second dimension, memorizing learning (Rote Learning) and meaningful learning are distinguished.(Karyanti dkk., 2016) 
The process of learning can occur not only through a consciousness (thinking), but also through instincts that exist within the person. The thing is, what's instinct? Instinct, or what is often referred to as instinct, is an ability that humans have besides their ability to reason (thinking brain operation). The brain's role is no longer dominant in instincts, or instincts.

It is therefore not needless to conclude that education has an important role to play in sustaining human survival, both individually, in communities, in culture, and as a country. Maintaining and performing life properly and perfectly as a power point for every creature activity including humans The difference is that by learning, humans maintain and perform their lives. There is a distinctive practice from a number of human activities which separates it from other human activities such as relaxing while dreaming and dreaming during the pilgrimage in Mecca. It is called tasks with a unique nature, reading.

So where's the uniqueness? This one activity, in the process, concentrates or focuses the perpetrator. The attacker carries out the focus of death on something that is made an object of learning after he has become aware of it. Without this knowledge, there will be no real learning activity, because consciousness is the main motor of all psycho-physical activities of the human movement. Human beings may conduct learning tasks with his mind, and think, feel, and behave in a fairly organized and orderly way. Their relative nature indicates human ability's limitations. This can be proven, for example by careless behavior, or mistakes made by humans (human error) when carrying out its activities, including when carrying out learning activities. Failure or error is caused by the instability of an individual's psycho-physical condition

\section{Kelvin Strategy: The Most Critical Result Is the Process}

Kelvin in Educational Psychology provides a different learning process approach where the idea of learning in class is based on achieving learning outcomes through the use of knowledge or skills for learning in a non-school environment. Of example, learning to read and learn to solve arithmetic problems is the main goal of a curriculum's elementary school because skills are meant to be used not only in the classroom, but also outside. 
Kelvin believed that in the form of abilities and skills, the instructor must be able to transfer his expertise in a fun way. Learning fun is certainly a good thing to do, but it makes learning more useful and fun.Since students have a' golden standard' teaching period: in fact, teachers want the best for each student, even if we cannot do it all at once.(Babu dkk., 2017; Henry dkk., 2015; Jarosz dkk., 2017)

Teachers are teaching positions or jobs requiring teacher expertise. Those who articulate well can't be called an instructor in certain areas. To become an educator needs special needs, in particular as the qualified instructor who has to teach and teach in various other sciences must be encouraged and trained over a certain period of education and pre-service learning.(Ismail dkk., 2013; Sutton, 2016).

\section{The Ability Of Students In The Literature}

The learning process that can satisfy students ' critical thinking skills cannot be carried out in a one-way learning process. One-way learning, or teacher-centered learning, will fuel criticism by students in their approach to teaching. Students receive material from one source that tends to accept it and cannot criticize it. The ability to think critically is constructed through exploring material from a variety of ways in Pesantren. (Haningsih, 2008; Maharani dkk., 2018; Velasufah \& Setiawan, 2019)

The ability to associate information with the real world is accomplished by making students see real life. It is important to understand through teaching material to inspire student encouragement in life. The ability of teachers to connect each teaching material with real life will enhance mastery of the material by students, especially in the world of basic education that is still thinking concretely. Combining and using the content will improve students ' development ability.

Both teachers in all fields need to learn communications information technology. The mastery of interaction IT is not at knowledge level, but the study of its use. The methods of learning that can handle this rely on the use of different learning resources. From traditional resources for learning to use digital resources for learning. Students use both offline 
and online electronic outlets. The production of products based both on audio and audiovisual communications technology.

Collaborative abilities reflect an acceptability mindset towards others and the communication of expectations with others. The model for collaborative research enables students to play, conduct and be responsible in their respective roles. The willingness of individuals to plan for their future, self-determination and self-employment will decrease. Each skill is collaborated in each, so that competence and results are improved. There are not monotonous opportunities and complex learning experiences. Types of education tailored to gain the skills. The mastering of one skill is practiced through a variety of methods which can adjust additively, visually and kinesthetically in a balanced manner. It gives every student the same chance of learning.

The use of technology, in particular information technology, enables students to keep up with developments in technology and to obtain different forms of learning resources and media. More and more diverse learning opportunities allow students to explore teaching materials based on the learning styles and interests of the students.

Curriculum links, or integrated curriculum, allows students to link up content and communication skills to make learning more relevant and to explore the advantages of education. This education is supported by a collaborative study environment that maximizes the potential of students. The student's understanding could be improved through high level visualization and the use of visual media.

In Adri Efferi, (Putra \& Idawati, 2018), states that a teaching related to a particular curriculum material the principles of implementation are influenced by four main components, namely material carrier, material presenter, approach and recipient of the material. The arrangement of the curriculum material is called a learning strategy teach.

Formal assessment indicates a system control at the end of a learning process. The students are assessed for their mastery, able to identify learning difficulties, and are usefully positioned for community structured training by means of formative evaluation and self-assessment. 


\section{E. Conclusion}

The purpose of this study is to provide general knowledge and implementation in Islamic boarding schools on digital age literacy. The educator can use a set with different skills and a mix of modern and traditional Arabic books to introduce digital age literacy. Students' ability to think critically through the learning process of Kelvin Seivert can at least improve basic literacy compared to the 21st century in writing and scientific thinking. Digital age literacy implementation should be carried out on an ongoing basis and adapted to student development. Implementing digital age literacy often involves cooperation and coordination from different groups including parents, state, educational practitioners, schools, and society.

Further study recommendations can concentrate on one main thought material and place it in technology media literacy at various Islamic boarding schools in Indonesia. Research focuses on technological advances in video education in Islamic boarding schools on the internet or in google.

\section{Bibliography}

Abdulkarim, A., Ratmaningsih, N., \& Anggraini, D. N. (2018). Developing Civicpedia as a Civic Education E-Learning Media To Improve Students' Information Literacy. Journal of Social Studies Education Research, 9(3), 45-61.

Babu, G., Suresh, P., \& Pariventhan, K. (2017). Enhancement of learning through collaborative learning techniques. New Man Journal of Multidisciplinary Studies, 4, 29-38.

Barreiro, M. P. R. (2018). The use of critical thinking skills to detect bias in written press. Revista Boletín Redipe, 7(6), 74-83.

Basri, H., \& As, A. R. (2018). Improving The Critical Thinking Ability of Students to Solve Mathematical Task. JIPM (Jurnal Ilmiah Pendidikan Matematika), 7(1), 13-21.

Deng, Z., \& Gopinathan, S. (2016). PISA and high-performing education systems: Explaining Singapore's education success. Comparative Education, 52(4), 449-472. 
Dixon, M. (2017). Reflecting on writing for teaching. Metaphor, 4, 44.

Eddles-Hirsch, K. (2015). Phenomenology and educational research. International Journal of Advanced Research, 3(8).

Fidalgo, R., Torrance, M., Rijlaarsdam, G., van den Bergh, H., \& Álvarez, M. L. (2015). Strategy-focused writing instruction: Just observing and reflecting on a model benefits 6th grade students. Contemporary Educational Psychology, 41, 37-50.

Germaine, R., Richards, J., Koeller, M., \& Schubert-Irastorza, C. (2016). Purposeful Use of 21st Century Skills in Higher Education. Journal of Research in Innovative Teaching, 9(1).

Graham, M., \& Dutton, W. H. (2019). Society and the internet: How networks of information and communication are changing our lives. Oxford University Press.

Haningsih, S. (2008). Peran strategis pesantren, madrasah dan sekolah islam di Indonesia. El Tarbawi, 1(1).

Henry, M., Réjou-Méchain, M., Jara, M. C., Wayson, C., Piotto, D., Westfall, J., Fuentes, J. M. M., Guier, F. A., Lombis, H. C., \& López, E. C. (2015). An overview of existing and promising technologies for national forest monitoring. Annals of Forest Science, 72(6), 779788 .

Hidayat, S., \& Fadillah, E. N. (2019). Development of Assessment Instruments In Measuring Critical Thinking Skills of Senior High School Participants of Biology Subject. Journal of Physics: Conference Series, 1241, 012040.

Howard, L. W., Tang, T. L.-P., \& Austin, M. J. (2015). Teaching critical thinking skills: Ability, motivation, intervention, and the Pygmalion effect. Journal of Business Ethics, 128(1), 133-147.

Ismail, M., Rahim, P. R. M. A., \& Yusoff, M. S. M. (2013). Educational Strategies to Develop Discipline among Students from the Islamic Perspectives. Procedia - Social and Behavioral Sciences, 107, 80-87. https://doi.org/10.1016/j.sbspro.2013.12.402

Jarosz, A. F., Goldenberg, O., \& Wiley, J. (2017). Learning by invention: Small group discussion activities that support learning in statistics. Discourse Processes, 54(4), 285-302. 
Karyanti, R., Yulianti, D., \& Baharuddin, B. (2016). Penerapan Pembelajaran Kooperatif Tipe Stad untuk Meningkatkan Ketrampilan Proses Sains dan Prestasi Belajar. Jurnal Teknologi Informasi Komunikasi Pendidikan (Old), 4(2).

Maharani, D. I., AY, M. H., \& Arifin, I. (2018). Manajemen Pembelajaran Pondok Pesantren. JMSP (Jurnal Manajemen Dan Supervisi Pendidikan), 1(1), 17-23.

McPeck, J. E. (2016). Critical thinking and education. Routledge.

Nadri, Y., \& Azhar, A. (2017). Self-Assessment of Critical Thinking Skills in EFL Writing Courses at the University Level: Reconsideration of the Critical Thinking Construct. Arab World English Journal, December 2016 ASELS Annual Conference Proceedings.

Nugrahanto, S., \& Zuchdi, D. (2019). Indonesia PISA Result and Impact on The Reading Learning Program in Indonesia. International Conference on Interdisciplinary Language, Literature and Education (ICILLE 2018).

Putra, P., \& Idawati, I. (2018). Telaah Kurikulum dalam Mata Pelajaran AlQur'an Hadist di Madrasah Ibtidaiyah. JIP: Jurnal Ilmiah PGMI, 3(2), 108-119. https://doi.org/10.19109/jip.v3i2.1645

Ramdhani, M. A., \& Muhammadiyah, H. (2015). The Criteria of Learning Media Selection for Character Education in Higher Education.

Ratri, S. Y. (2015). Student factor infl uencing Indonesian student reading literacy based on PIRLS data 2011. Journal Of Education, 1(1).

Scott, I. (2018). Designing the South African Higher Education system for student success. Journal of Student Affairs in Africa, 6(1), 1-17.

Setiawan, A. R. (2019). Is this Educational World We Created?

Short, M. N., \& Keller-Bell, Y. (2019). Essential skills for the 21st century workforce. In Handbook of Research on Promoting Higher-Order Skills and Global Competencies in Life and Work (pp. 134-147). IGI Global.

Sutton, R. (2016). Educational Psychology.

Suwono, H. (2017). School literary movement in Indonesia: Challenges for scientific literacy. International Conference on Education (ICE2) 2018: Education and Innovation in Science in the Digital Era, 309-317. 
Suwono, H., Mahmudah, A., \& Maulidiah, L. (2017). Scientific literacy of a third year biology student teachers: Exploration study. KnE Social Sciences, 269-278.

Teo, P. (2019). Teaching for the 21st century: A case for dialogic pedagogy. Learning, Culture and Social Interaction, 21, 170-178.

Ulger, K. (2016). The relationship between creative thinking and critical thinking skills of students.

Van Knippenberg, D., Dahlander, L., Haas, M. R., \& George, G. (2015). Information, attention, and decision making. Academy of Management Briarcliff Manor, NY.

Velasufah, W., \& Setiawan, A. R. (2019). Nilai Pesantren sebagai Dasar Pendidikan Karakter. 